\title{
Yurtdışı İşçi Gelirleri ve Hollanda Hastalığı: Seçilmiş Ülkeler İçin Bir Panel Veri Analizi
} \begin{abstract}
dizi parametre üzerinde etkili olan yurtdışı işçi gelirleri (YIG)'nin, reel döviz kurunu etkilemesi dolayısıyla dış ticaret yapısı üzerinde de etkileri söz konusudur. YíG'nin yanı sıra doğrudan yabancı yatırımlar, portföy yatırımları ve dış yardım gibi çeşitli sermaye akımları yoluyla ortaya çıkabilen ve literatürde Hollanda Hastalığı olarak adlandırılan bu olayın çıkış noktası, doğal kaynak keşiflerinden dolayı dış finansman girişlerinde yaşanan ani ve büyük hacimli artışlar olmuştur. Bu çalışmada, en fazla Yíg elde eden ülkeler arasından seçilen 9 ülkeye ait 1990-2014 dönemi panel verileri kullanılarak, YíG'nin ev sahibi ülke döviz kurunda bir reel değerlenmeye yol açıp açmadığının tespit edilmesi amaçlanmıştır. Çift yönlü rassal etkiler tahmincisinin kullanıldığı analizden elde edilen bulgular, bir Hollanda Hastalığı belirtisi olarak, YíG'nin reel değerlenmeye yol açtığına işaret etmektedir.
\end{abstract}

Anahtar Kelimeler: Yurtdışı İşçi Gelirleri, Hollanda Hastalığı, Panel Veri Analizi
Emrah Eray Akça ${ }^{1}$

Harun $\mathrm{Bal}^{2}$

Workers' Remittances and Dutch Disease: A Panel Data Analysis for Selected Countries

\section{Abstract}

Workers' remittances, that have influence on a range of parameters like production, investment and employment structure of host country, exert effects on the foreign trade structure as well through its impact on real exchange rate. Besides the capital inflows like foreign direct investment, portfolio investment and foreign aid, workers remittance can also lead to Dutch Disease, a phenomena known in literature resulted from sudden and massive increase in foreign capital inflow because of natural resource discovery. The study aims to determine whether the workers' remittances led to a real appreciation in the host country's currency employing panel data for the period of 1990-2014 for 9 countries selected from those receiving the highest workers' remittance. Findings from the analysis of the two-way random effects estimation suggest that, as a Dutch Disease Symptom, workers' remittances lead to a real appreciation of the home countries' currencies.

Keywords: Workers' Remittances, Dutch Disease, Panel Data Analysis

\section{Giriş}

2016 yılı itibariyle yaklaşık 250 milyondan fazla kişinin (dünya nüfusunun \%3,4'ü) kendi ülkelerinin dışında yaşaması, göç akımlarının ulaştığı boyutu gözler önüne sermektedir. Dünyadaki en büyük göç akımı sıralamasında Meksika'dan ABD'ye yönelik göçler ilk sırayı alırken, bunu Rusya-Ukrayna ve Bangladeş-Hindistan göç hareketleri takip etmektedir. En fazla göçmenin bulunduğu ülkeler sırasıyla ABD, Suudi Arabistan, Almanya ve Rusya olarak görülmektedir. Toplam nüfus içerisindeki payları baz alındığında ise en fazla göçmen işçiler sırasıyla Katar (\%91), Birleşik Arap Emirlikleri (\%88) ve Kuveyt (\%72)'de bulunmaktadır. Uluslararası göç akımlarının \%6'sını mülteci akımları oluşturmaktadır. 2015 yılı itibariyle dünya civarında yaklaşık 15 milyondan fazla mülteci bulunmaktadır. Şekil 1'de, göç akımlarının 1970'lerden günümüze gelişim seyri gösterilmektedir (World Bank, 2016).

\footnotetext{
${ }^{1}$ Arş. Gör., Çukurova Üniversitesi, İktisadi ve İdari Bilimler Fakültesi, İktisat Bölümü, eakca@cu.edu.tr

${ }^{2}$ Prof. Dr., Çukurova Üniversitesi, İktisadi ve İdari Bilimler Fakültesi, iktisat Bölümü, harunbal@cu.edu.tr
} 
Şekil 1: Göç Akımlarının Gelişim Seyri (Stok-Milyon Kişi)

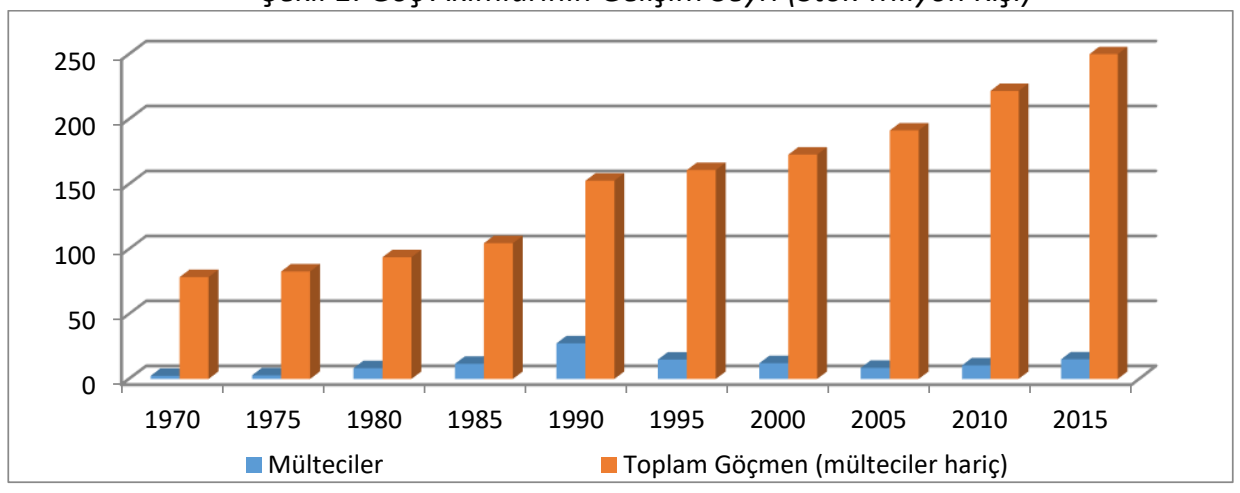

Toplam göçmen sayısının 1970’lerden itibaren sürekli olarak arttığı gözlenmektedir. Göçmen sayısındaki bu artışa paralel olarak yurtdışı iş̧̧i gelirleri (YIG)'nin uluslararası sermaye akımları içindeki payı ve önemi de artmıştır. 1970'de 37 milyar dolar olan toplam dünya YiG, 2015 yılı itibariyle yaklaşık 550 milyar dolar düzeyine ulaşmıştır. Yine toplam dünya Yíg'nin toplam dünya milli geliri içindeki payı da 1970'deki binde 43 düzeyinden 2015'de binde 76 düzeyine yükselmiştir. Bunun yanı sıra, YiG'nin önemli bir kısmının da kayıt dışı olması dolayısıyla istatistiklere yansımadığı bilinmektedir (World Bank, 2016). YiG'nin dünyadaki gelişim seyrine bakıldığında 2000 yılından sonra yaşanan keskin dönüşüm dikkat çekmektedir. Bu yıla kadar oldukça yavaş ve istikrarlı bir şekilde artan YiG, 2000'den sonra oldukça hızlı ve sürekli bir artış eğilimi içerisine girmiştir. Bu gelişim trendinde, 2000'li yılların 2. Dünya Savaşı sonrası en hızlı büyüme dönemi olmasının ve faktör hareketliliğinde yaşanan serbestleşmeye yönelik uygulamaların büyük etkisi olmuştur. 2000-2015 dönemindeki 16 yılda toplam YiG \% 350 oranında artarak müthiş bir performans sergilemiştir. Bu artışta en büyük rolü Hindistan, Çin, Bangladeş ve Pakistan gibi Asya ülkelerinden yabancı ülkelere göç eden işçiler oynamıştır. En fazla YíG'ni transfer eden ülkeler arasında ise ABD, Suudi Arabistan, İsviçre, Çin, Rusya ve Almanya öne çıkmaktadır (WB, 2017).

YíG'ndeki artışa paralel olarak bu gelirlerin ev sahibi ülke ekonomilerindeki önemi de artmıştır. Özellikle iktisadi kalkınma çabası içerisinde olan gelişmekte olan ülkeler (GOÜ)'in sermaye yetersizliği problemi yaşadıkları göz önüne alındığında, bu sermaye akımlarının söz konusu ülkeler açısından önemi daha da artmaktadır. Ev sahibi ülkeyi politik ya da ekonomik yönden herhangi bir yükümlülük altına sokmayan YíG, aynı zamanda diğer sermaye akımlarına nispeten daha istikrarlı bir gelişim trendi sergilemesi nedeniyle de ev sahibi ülke ekonomileri için önem taşımaktadır.

Yí, parasal getirilerinin yanı sıra, eğitim, sağlık ve cinsiyet eşitliği gibi beşeri sermaye göstergelerindeki olumlu gelişmelerle de ilişkilidir. Burada, YiG'ndeki artışa paralel olarak okuldan ayrılma oranlarındaki azalış ve ortalama çocuk doğum ağırlığındaki artış gibi etkilere göndermede bulunulmaktadır. YiG aynı zamanda söz konusu ülkenin uluslararası alandaki güvenilirliğini artırarak daha elverişli şartlarda yabancı kredi erişimini kolaylaştırmaktadır. Bir ülkenin çeşitli risk düzeylerindeki borç sürdürülebilirliğini analiz eden Dünya Bankası, 2009'dan itibaren bu analiz hesaplamalarına YíG'ni de dâhil etmiştir (Ratha, 2013). YíG'nin transfer edilmesi esnasında katlanılan işlem maliyetlerinin olabildiğince düşük tutulması, YíG'nden elde edilecek fay- 
danın maksimize edilmesine yol açabilir. Bu gelirlerin transferinde kullanılan aracı kurumlar arasındaki rekabette yaşanan artış, yüksek miktarda Yíg transferlerinde bu maliyetleri düşürmektedir (WB, 2017).

YíG'nin uluslararası sermaye akımları içerisinde artan önemi, bu akımların ev sahibi ülke ekonomilerine ne yönde ve nasıl katkı sundukları üzerine yoğun araştırmaları da beraberinde getirmiştir. YiG'nin ev sahibi ülkede yoksulluk düzeyini azaltması ve refah düzeyini yükseltmesi gibi pozitif makroekonomik sonuçlar yarattığı bulgularına ulaşan çalışmaların yanı sıra (bkz. Adam ve Page, 2005; Acosta vd., 2008), yakın dönem literatüründe YiG'nin dolaylı yollarla olumsuz makroekonomik sonuçlar doğurabileceği üzerinde de durulmaktadır (bkz. Lartey vd., 2012; Rabbi vd., 2013; Roy ve Dixon, 2016). Bu olumsuz makroekonomik sonuçların temel olarak reel döviz kuru (RDK) aracılığıyla gerçekleşeceği vurgulanmaktadır. Buna göre, YíG'ndeki artışın ev sahibi ülkenin yerel para biriminde bir reel değerlenmeye yol açması ve bu yolla da ticarete konu olan mallarda rekabet gücünü zayıflatması dolayısıyla ekonomik büyümeyi negatif yönde etkilemesi söz konusudur. Sezgisel olarak düşünüldüğünde, YíG'nin özellikle sanayileşme çabası içerisinde olan GOÜ'in sanayileşme süreçlerine katkı sunmaları beklenir. Bununla birlikte yapılan analizlerin çoğunda bu sermaye akımlarının sanayileşme sürecine katkı sunmaktan ziyade, bir sanayisizleşmeye yol açtığı gibi aksi bulgulara da ulaşılabildiği görülmektedir. YíG'nin ev sahibi ülkenin yerel para biriminde reel değerlenmeye yol açması dolayısıyla olumsuz makroekonomik sonuçlar doğurması, literatürde Hollanda Hastalığı $(\mathrm{HH})^{\prime}$ nın önemli sebeplerinden biri olarak ifade edilmektedir. HH, YiG'nin yanı sıra doğrudan yabancı yatırımlar, portföy yatırımları, dış yardım ve doğal kaynak sektöründeki canlanmanın yol açtığı sermaye akımları gibi pek çok şekilde ortaya çıkabilen bir olgudur.

En fazla yurtdışı işçi geliri elde eden ülkeler arasından seçilen 9 ülke için 1990-2014 dönemi kapsamında, YiG'nin söz konusu ülkelerde bir HH etkisi yaratıp yaratmadığının sorgulandığı bu çalışmanın geri kalanı şu şekilde organize edilmiştir. YíG ve HH bağlantısına dair teorik açıklamaların sunulduğu ikinci bölümün ardından, üçüncü bölümde ilgili ampirik literatür özetine yer verilmektedir. Veri seti, yöntem ve ampirik bulguların yer aldığı dördüncü bölümün ardından çalışmamız, sonuç ve bu sonuçlara ilişkin değerlendirmelerin yer aldığı beşinci bölümle tamamlanmaktadır.

\section{Yurtdışı İşçi Gelirleri ve Hollanda Hastalığı}

Yurt dışında çalışan birisinin ülkesine gönderdiği dövizler ev sahibi ülke bakımından üç farklı bileşene ayrılmaktadır. Uluslararası sermaye akımları arasında karşılıksız özel transferler olarak adlandırılan Yíg (cari işlemler hesabının cari transferler kaleminde yer almakta), yurtdışında bir yıl ya da daha fazla süre ikamet etmiş olan birisinin, bağlı bulunduğu ülkedeki kimselere gönderdiği dövizi ifade etmektedir. Yurtdışında bir yıldan daha kısa süre kalınması durumunda ev sahibi ülkeye transfer edilen dövizler ise ev sahibi ülke bakımından iş̧̧i ücreti (cari işlemler hesabının gelir kaleminde yer almakta) niteliği taşımaktadır. Bir ülkeden diğerine göç etmiş olan göçmenlerin ülkelerine gönderdikleri dövizler ise finansal kalemler içerisinde yer almaktadır (Jongwanich, 2007: 2).

Yurtdışında işçi olan kimseler bağlı bulundukları ülkeye farklı güdülerle döviz transfer edebilirler. Bir kısım işçiler fedakârlık etme (altruism) faktörünün ağır bastığı nedenlerle bağlı bulundukları ülkedeki yakınlarına istikrarlı bir şekilde döviz gönderirken, aile bağı güçlü olmayan diğer bir kısım iş̧̧iler ise sadece ülkesinde ekonomik koşullar kötüleşince yakınlarına döviz transfer etmektedirler. Yurtdışına göç eden işçilerin ülkelerine döviz transfer etmelerinin bir diğer 
nedeni de ülkelerindeki yatırım fırsatlarından yararlanma istekleridir. Yurt dışında çalışan işçilerin kar elde etme arzuları dolayısıyla gerçekleşen bu özel transfer şeklinde (self-interest) ev sahibi ülke hane halkı sadece aracı rolü üstlenmektedir (Arı ve Özcan, 2012: 156). Aşağıdaki şekil 2'de toplam dünya YíG'nin toplam dünya milli geliri içindeki payının 1980-2015 dönemindeki gelişim seyri gösterilmektedir.

Şekil 2: Toplam Dünya Yurtdışı Iş̧̧i Gelirleri (\% GSYH)

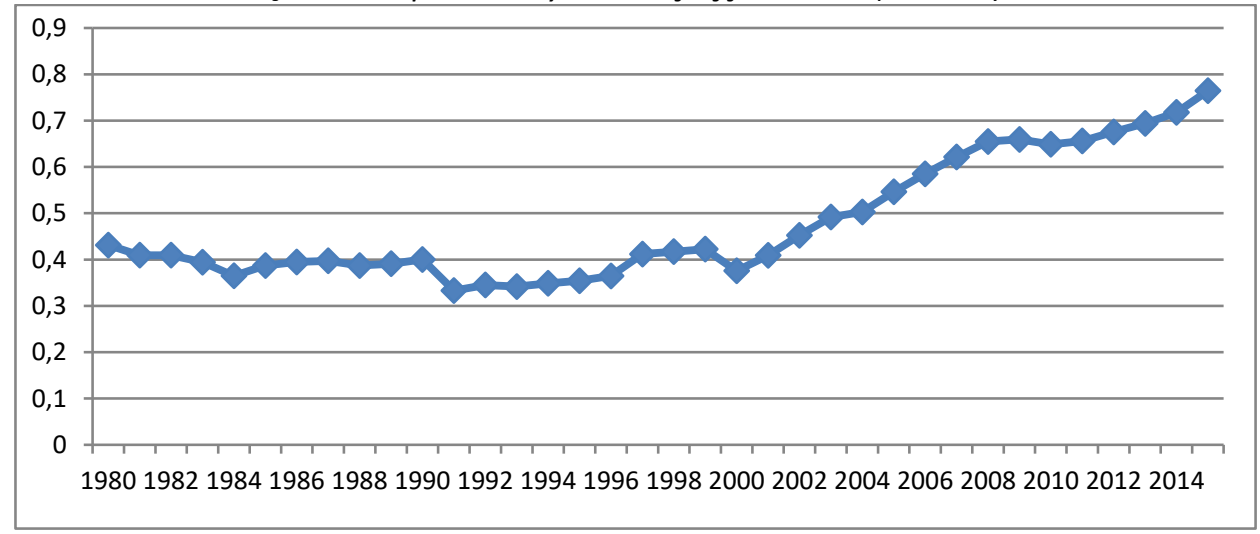

Kaynak: World Bank (2017), http://databank.worldbank.org/data/home.aspx

YíG'nin ev sahibi ülkenin cari işlemler hesabını iyileştirmesi dolayısıyla ekonomik büyümeye pozitif katkılar sunması beklentilerine karşın, dolaylı yollarla olumsuz makroekonomik sonuçlar doğurduğu tartışmaları yaygınlaşmıştır. Bu tartışmalar HH çerçevesinde ele alınmaktadır. Corden ve Neary (1982), HH'nı kısaca kaynak girdisinde ya da kaynak fiyatlarında dışsal bir artışın ulusal paranın reel değerlenmesine yol açması, buna bağlı olarak da imalat sanayi sektörünün rekabet gücünün azalması şeklinde tanımlamışlardır. Doğal kaynak sektöründeki canlanma dolayısıyla ülkeye giren döviz miktarındaki ani artış, ülke parasını değerli hale getirmekte ve bunun sonucunda yurtiçinde üretilen malları nispeten pahalılaştırarak ülkenin dış pazardaki rekabet gücünü zayıflatmaktadır. Ayrıca değerlenen para dolayısıyla ithal mallar ucuzlamakta ve yerli üretimin iç pazardaki durumu bundan olumsuz etkilenmektedir. Belirli koşullar altında bu durum, ekonomik büyüme oranlarının beklenilenin altında gerçekleşmesine yol açmaktadır.

Bir ülkenin ulusal parasının aşırı değerlenmesinin, $\mathrm{HH}$ ile ilgili ilk belirti olduğu ifade edilmektedir. Ancak daha sonra imalat sanayi sektöründeki gerileme ile birlikte hizmet sektörünün gelişimi ve ücretlerde yaşanan artışın HH ile ilgili diğer belirtiler olduğu anlaşılmıştır (Gylfason, 2001: 1). Ticareti yapılabilir mallar sektörü içinde ilerleyen ve gerileyen sektörlerin bir arada yaşadığını ifade eden HH terimi asıl olarak, 1960'larda Hollanda'nın doğalgaz keşfinin Hollanda imalat sanayisi üzerindeki negatif etkisini tanımlamak için kullanılmıştır. Kuzey Denizi'nde meydana gelen petrol ve doğalgaz keşiflerinin ardından Hollanda, Norveç ve İngiltere gibi ekonomilerin sanayi yapılarındaki değişim dikkat çekici olmuştur. Bu ülkelerde meydana gelen petrol ve doğalgaz keşiflerinin imalat sanayi sektörlerinde çıktı ve istihdamı azaltması (sanayisizleştirme) olayı ' $\mathrm{HH}$ ' olarak adlandırılmıştır. Ancak HH hipotezi, birincil ürün (doğal kaynak, hammadde) ihracatındaki hızlı büyümenin iktisadi büyümeyi negatif yönde etkileyeceğini iddia ederken, imalat sanayi sektörünün büyümenin motoru olduğunu (Kaldor Hipotezi) ve bu sektördeki bir 
daralmanın doğal kaynak sektöründeki canlanmadan daha önemli olduğunu varsaymaktadır. Sanayisizleşmenin bir hastalık olarak ifade edilmesi, imalat sanayi sektörünün kendine has büyüme artırıcı özelliklerinden (ölçeğe göre artan getiri, yaparak öğrenme, yayılma etkisi ya da diğer pozitif dışsallıklar) kaynaklanmaktadır (John, 2011: 169).

HH temel modelini açıklamak için dışa açık küçük bir ekonomi varsayımıyla birlikte üretim sektörleri, kazanç patlaması yaşayan sektör (doğal kaynak), gerileyen sektör (kaynak dışı ticarete konu olan sektör- imalat sanayi) ve ticarete konu olmayan sektör (hizmetler) olmak üzere üç ayrı grupta sınıflandırılmaktadır. Modeli oluştururken dışa açık küçük ülke varsayımı yapılmasının nedeni, uluslararası rekabete tabi olan ticareti yapılabilir malların fiyatlarının dünya piyasasında belirleniyor olması ve söz konusu ülkenin dünya fiyatlarını etkileyemeyecek kadar küçük olması gerektiğinden kaynaklanmaktadır. Her sektör çıktısının sektöre özel bir faktör tarafından üretildiği ve işgücünün tüm sektörlerde ücretleri eşitleyecek şekilde sektörler arası hareketli olduğu varsayılmaktadır. Ayrıca tüm üretim faktörlerinin uluslararası düzeyde hareketsiz olduğu ve fiyatlarının esnek olduğu kabul edilmektedir. Kazanç patlaması yaşayan sektör ile gerileyen sektörün fiyatları dünya piyasasında belirlendiği için veri kabul edilirken, ticarete konu olmayan malların fiyatı yurt içi arz ve talep koşulları tarafından belirlenmektedir (Oomes ve Kalcheca, 2007: 10). HH mekanizmasının işlerliği tam istihdam dengesi ve statik teknoloji varsayımına dayanmaktadır. Ayrıca modelin temel varsayımları arasında parasal faktörlerin göz ardı edilmesi, bir ekonomide üretilen çıktı ile harcama düzeyinin eşit olması ve emtia ya da faktör piyasalarında bozuklukların söz konusu olmaması yer almaktadır (Corden ve Neary, 1982: 826).

$\mathrm{HH}$ temel modelinde, ticarete konu olan malların fiyatlarının $\left(\mathrm{P}_{\mathrm{T}}\right)$ ticarete konu olmayan malların fiyatlarına $\left(\mathrm{P}_{\mathrm{N}}\right)$ oranı RDK olarak tanımlanmıştır ( $\left.\mathrm{RDK}=\mathrm{P}_{\mathrm{T}} / \mathrm{P}_{\mathrm{N}}\right)$. Kaynak gelirlerindeki ani artışa bağlı olarak toplam talepte meydana gelen artış, ticarete konu olmayan malların fiyatlarını artırmaktadır. HH modeli çerçevesinde nispi fiyatlarda bir reel değerlenmeyi ifade eden bu durumda, ticarete konu olan sektörlerin (imalat sanayi) rekabet edebilirlik gücü zayıflayarak sektörün çıktı ve istihdam düzeyi azalmaktadır (dolaylı sanayisizleşme). Doğal kaynak sektöründeki canlanmadan dolayı büyümenin motoru olarak sayılan imalat sanayi sektörünün gerilemesinin bir sonucu olarak iktisadi büyüme dolaylı olarak engellenmiş olmaktadır (harcama etkisi). Ayrıca ticarete konu olan sektördeki fiyatların sabit olması durumunda, doğal kaynak sektöründeki canlanmanın bir sonucu olarak bu sektördeki emeğin marjinal verimliliği artmaktadır. Dolayısıyla doğal kaynak sektöründe emek talebi artmakta ve emek faktörü diğer sektörlerden bu sektöre hareket etmektedir. Bu etki iki kısma ayrılmaktadır. Birincisi, kaynak dışı ticarete konu olan sektördeki emeğin kazanç patlaması yaşayan kaynak sektörüne yönelmesinin bir sonucu olarak, kaynak dışı ticarete konu olan sektörde (imalat sanayi) çıktının azalmasıdır. Bu durum, ticarete konu olmayan sektör piyasasını kapsamadığı için ve bu yüzden ulusal paranın değerlenmesi söz konusu olmadığı için doğrudan sanayisizleşme olarak adlandırılmaktadır. İkinci olarak, ticarete konu olmayan sektördeki emeğin kazanç patlaması yaşayan doğal kaynak sektörüne hareket etmesinin bir sonucu olarak ticarete konu olmayan sektörün istihdamında ve çıktısında azalma meydana gelmektedir. Bu durum, harcama etkisine ilaveten ticarete konu olmayan sektörde talebin artmasına neden olmakta ve nispi fiyatlar daha da yükselmektedir. Bunun bir sonucu olarak kaynak dışı ticarete konu olan sektördeki emek faktörü, ticarete konu olmayan sektöre doğru yönelmekte ve harcama etkisinden kaynaklanan dolaylı sanayisizleşme olgusu daha da güçlenmektedir. Böylece her iki etki birleştirildiğinde doğrudan sanayisizleşmeyi (emeğin 
kaynak dışı ticarete konu olan sektörden kazanç patlaması yaşayan sektöre hareketi) tamamlayan dolaylı sanayisizleşme (emeğin kaynak dışı ticarete konu olan sektörden ticarete konu olmayan sektöre hareketi) ortaya çıkmaktadır (Corden, 1984: 361).

Gerçekte bu türden gelişmelere ani bir doğal kaynak keşfi neden olabileceği gibi, var olan bir doğal kaynağın dünya fiyatlarında meydana gelen ani yükselişler, dış finansman girişlerindeki ani artışlar veya bunun özel türlerinden biri olarak YíG'ndeki ani artışlar da neden olabilir (Bal, 2011). YíG'ndeki artış ev sahibi ülke piyasasında döviz arzı artışına yol açarak, ulusal para birimi üzerinde reel değerlenme yönünde baskı yaratmaktadır. Bir ülkenin uluslararası piyasada rekabet edebilirlik gücü ampirik literatürde geleneksel olarak RDK aracılığıyla ölçülmektedir.

Uluslararası sermaye akımlarının RDK üzerindeki etkisinin analiz edilmesinde kullanılan ampirik modellerin hemen hepsi Salter-Swan-Corden-Dornbush modelinden hareket etmektedir. Bu model, sermaye akımlarındaki bir artışın RDK'nu etkileme mekanizmasını ortaya koymaktadır. Buna göre, YiG'nden dolayı ev sahibi ülke hane halkının artan gelir düzeyine bağı olarak ticarete konu olan ve ticarete konu olmayan mallar üzerindeki artan harcama düzeyi, ticarete konu olmayan malların fiyatını kısa dönemde yükseltmektedir. Zira kısa dönemde ticarete konu olmayan malların arzı artırılamamaktadır. Ticarete konu olan malların fiyatları ise dünya piyasasında belirlenmektedir. Bu nedenle ticarete konu olmayan malların fiyatlarındaki artış $\mathrm{HH}$ modeli kapsamında bir reel değerlenme etkisi yaratmakta ve bu yolla da ihracatta rekabet edebilirlik gücü zayıflamaktadır (harcama etkisi). Ticarete konu olmayan malların fiyatlarındaki artış aynı zamanda üretim faktörlerinin ticarete konu olan sektörlerden ticarete konu olmayan sektörlere hareketine yol açarak (kaynak hareketi etkisi) ticarete konu olan sektörde çıktının azalmasına yol açmaktadır (Lartey vd., 2012: 378; Nikas ve Blouchoutzi, 2014: 53).

\section{Ampirik Literatür Özeti}

Hollanda'nın 1960'lı yıllarda yaşadığı olay, 1980'li yıllardan itibaren HH üzerine geniş bir literatürün oluşmasına yol açmıştır. Bu konudaki ilk çalışmalar ulusal paranın reel değerlenmesine, üretim faktörlerinin yeniden dağıtımına ve sanayisizleşmeye (de-industrilization) neden olan doğal kaynak fiyatlarındaki artışların ya da doğal kaynak keşiflerinin etkileri üzerine odaklanmışlardır. Daha sonraki çalışmalarda ise benzer etkiler yaratacağı düşünülen doğrudan yabancı yatırımlar, portföy yatırımları, dış yardımlar ve YíG gibi sermaye akımı yaratıcı faktörlerin makroekonomik sonuçları üzerinde durulmuştur. YiG ve HH arasındaki ilişkiyi inceleyen çalışmalarda YiG'nin RDK üzerindeki etkisi sorgulanmıştır. Ampirik literatürde YiG ve RDK arasındaki ilişkinin yönü net olmamakla birlikte, yapılan çalışmalarda çoğunlukla YíG'nin yerel para biriminde bir reel değerlenmeye yol açtığı sonucuna varılmıştır.

1980-2000 dönemi kapsamında Cape Verde ekonomisi için YiG ve HH bağlantısını sorgulayan Bourdet ve Falck (2003), YiG'nin yerel para biriminde çok küçük bir reel değerlenme etkisi yarattığı sonucuna varmışlardır. Bu nedenle Yíg'nin ticarete konu olan sektörlerin rekabet edebilirlik gücünü kısıtlayıcı etkisi oldukça sınırlı kalmaktadır. Yazarlar, Cape Verde'nın başarısını adaya yapılan resmi dış yardımların büyüme stratejilerinde kullanılmasına ve ada ekonomisinin daha ihracata yönelik bir gelişim stratejisi benimsemesine dayandırmışlardır. 13 Latin Amerika ve Karayip ülkesine ait 1979-1998 dönemi yıllık panel verilerini kullanarak sabit etkiler tahmincisiyle YiG ve HH bağlantısını inceleyen Amuedu-Dorantes ve Pozo (2004), bu ülkelere gelen YíG'nin uluslararası rekabet edebilirlik gücünü zayıflatması nedeniyle HH etkisi yarattığı sonucuna ulaşmışlardır. 
En az gelişmiş ülke grubu için RDK'nun dinamiklerini ve sermaye akımlarının RDK üzerindeki etkisini 1970-2004 dönemi yıllık verileriyle inceleyen Sy ve Tabarraei (2010), RDK'ndaki değişikliklerin \% 57'sinin Balassa-Samuelson etkisiyle ve \% 19'unun da sermaye akımları ile açıklandığı bulgusunu elde etmişlerdir. Yazarlar ayrıca, sermaye akımlarının zayıf bir HH etkisi yarattığını ifade etmişlerdir. Bir grup gelişmekte olan ve geçiş ekonomilerine ait 1990-2003 dönemi ayrıştırılmış sektörel verilerini kullanarak Yíg ile HH ilişkisini sorgulayan Lartey vd. (2012), YíG'nin harcama ve kaynak etkisi yaratarak HH'na yol açtığı bulgusuna ulaşmışlardır. Yazarlar ayrıca kaynak hareketi etkisinin sabit döviz kuru rejimlerinde daha güçlü olduğunu ifade etmişlerdir.

Johansen eş bütünleşme tekniğini ve hata düzeltme modelini kullanarak 1971-2011 dönemi kapsamında Bangladeş'in elde ettiği YiG'nin makroekonomik sonuçlarını HH çerçevesinde inceleyen Rabbi vd. (2013), HH'na işaret eden bulgulara ulaşmışlardır. Buna göre Bangladeş'e gelen YiG, ulusal para biriminde reel değerlenme etkisi yaratarak Bangladeş'in dış ticarette rekabet edebilirlik gücünü zayıflatmaktadır. Yazarlar, Bangladeş'in HH etkilerinden kurtulabilmesi için ülkede ticaret engellerinin aşamalı bir şekilde kaldırılması, dış ticarette çeşitlendirilmeye gidilmesi ve YíG'nin ticarete konu olmayan sektörlerden yatırıma yönelik ticarete konu olan sektörlere yönlendirilmesi gerektiği önerilerinde bulunmuşlardır. Etiyopya’ya yönelik dış yardım ve YíG şeklinde gerçekleşen büyük sermaye akımlarının HH etkisi yaratıp yaratmadığını farklı eş bütünleşme tekniklerini kullanarak araştıran Martins (2013), dış yardımların HH'na yol açmadığı, YiG'nin ise çok zayıf bir HH belirtisi gösterdiği sonucuna ulaşmıştır. Yazarın çalışmasından elde ettiği temel sonuçlar, uzun dönemde RDK'nun başlıca belirleyicisi olarak ticarette açıklık ve dış ticaret hadleri değişkenlerine işaret etmektedir. Ticarette açıklık düzeyindeki pozitif gelişmeler yerel para biriminin değerini düşürücü yönde etkide bulunurken, ticaret hadlerindeki iyileşmeler reel değerlenme yönünde işlev görmektedir. Bu sonuçlar bağlamında Etiyopya'nın ülkeye yönelik sermaye akımları kapsamında HH etkilerinden kaçındığı söylenebilir.

Bangladeş'in 1971-2008 dönemi yıllık verileriyle Johansen eş bütünleşme tekniğini ve hata düzeltme modelini kullanarak YiG ve HH bağlantısını inceleyen Chowdhury ve Rabbi (2014), bir HH belirtisi olarak, YíG'ndeki artışın dış ticarette rekabet edebilirlik gücünü zayıflattığı bulgusuna ulaşmışlardır. Dış ticaret hadlerindeki artışın da Bangladeş için benzer sonuçlar doğurduğunu öne süren yazarlar, mal ve sermaye piyasalarındaki açıklık ile nominal devalüasyonların ticarette rekabet edebilirlik gücünü artırdığını ifade etmişlerdir. En küçük kareler tahmincisini kullanarak iki küçük geçiş ekonomisi olan Arnavutluk ve Moldova'ya gelen YíG'nin makroekonomik etkilerini 1990-2010 dönemi kapsamında inceleyen Nikas ve Blouchoutzi (2014), YiG'nin Arnavutluk'ta HH'na yol açtığı, buna karşın Moldova'da böyle bir etki yaratmadığı sonucuna ulaşmışlardır. Yazarlar, YiG'nin ev sahibi ülkede nasıl ve hangi şekilde kullanıldığına vurgu yaparak, bu kaynakların iyi yönetilmesi sayesinde ekonomiye pozitif yönde katkı sunacağını ifade etmişlerdir. Buna göre Moldova ekonomisine giren YiG, Arnavutluk'a nispeten daha verimli yatırım alanlarında değerlendirilmektedir. 2003-2012 dönemi kapsamında sabit etkiler tahmincisini kullanarak Güney Asya ülkeleri (Bangladeş, Hindistan, Pakistan ve Sri Lanka) için Yíg ve HH ilişkisini sorgulayan çalışmalarında Roy ve Dixon (2016), YiG'nin bu ülkelerin yerel para birimlerinde bir reel değerlenmeye yol açtığını ve dolayısıyla HH etkilerinin ortaya çıktığını ifade etmişlerdir.

YíG'nin makroekonomik etkilerini inceleyen ve sonuçlara ilişkin çıkarımlarda bulunan çalışmaların hemen hepsinde, bu gelir akımlarının ev sahibi ülke ekonomisinde nasıl ve hangi alanda kullanıldığına vurgu yapılmaktadır. Dolayısıyla ele alınan ülke ya da ülke grubuna göre farklı so- 
nuçların elde edildiği ilgili ampirik literatür, ülkelere özgü bazı karakteristikler (ağılıklı harcamaların yapıldığı sektörler ve yatırım alanları gibi) konusunda da fikir vermektedir. Bizim çalışmamızda da, ulaşılabilir en güncel veri setleri ve uygun ekonometrik yöntemler eşliğinde en fazla yurtdışı işçi geliri elde eden ülkeler arasından seçilen 9 ülke için YíG'nin HH etkileri sorgulanarak, YiG'nin kullanım alanları ve ekonomik etkileri hakkında fikir sahibi olunması hedeflenmektedir.

\section{Veri Seti, Yöntem ve Bulgular}

Bu çalışmada YiG'nin makroekonomik etkileri bağlamında bir HH etkisi yaratıp yaratmadı̆̆ı, en fazla YíG elde eden ülkeler arasından seçilen 9 ülke (Bangladeş, Çin, Mısır, Hindistan, Endonezya, Meksika, Nijerya, Pakistan ve Filipinler)'ye ait 1990-2014 dönemi dengeli panel verileri ile analiz edilmiştir. Ülke seçiminde ekonometrik modelde yer alan değişkenlere ait verilerin varlığına da bağıı olarak en fazla YiG alan GOÜ dikkate alınmıştır. Dolayısıyla nispeten homojen bir panel havuzu oluşturmak amacıyla, önemli miktarda YiG alan Almanya ve Fransa gibi gelişmiş ülkeler çalışmaya dâhil edilmemiştir. Şekil 3 ve 4'te, çalışma kapsamında yer alan ülkelere gelen YiG'nin milli gelir içindeki paylarının gelişim trendi gösterilmektedir.

\section{Şekil 3. Yurtdışı İş̧̧i Gelirlerinin GSYiH Içcindeki Payları}

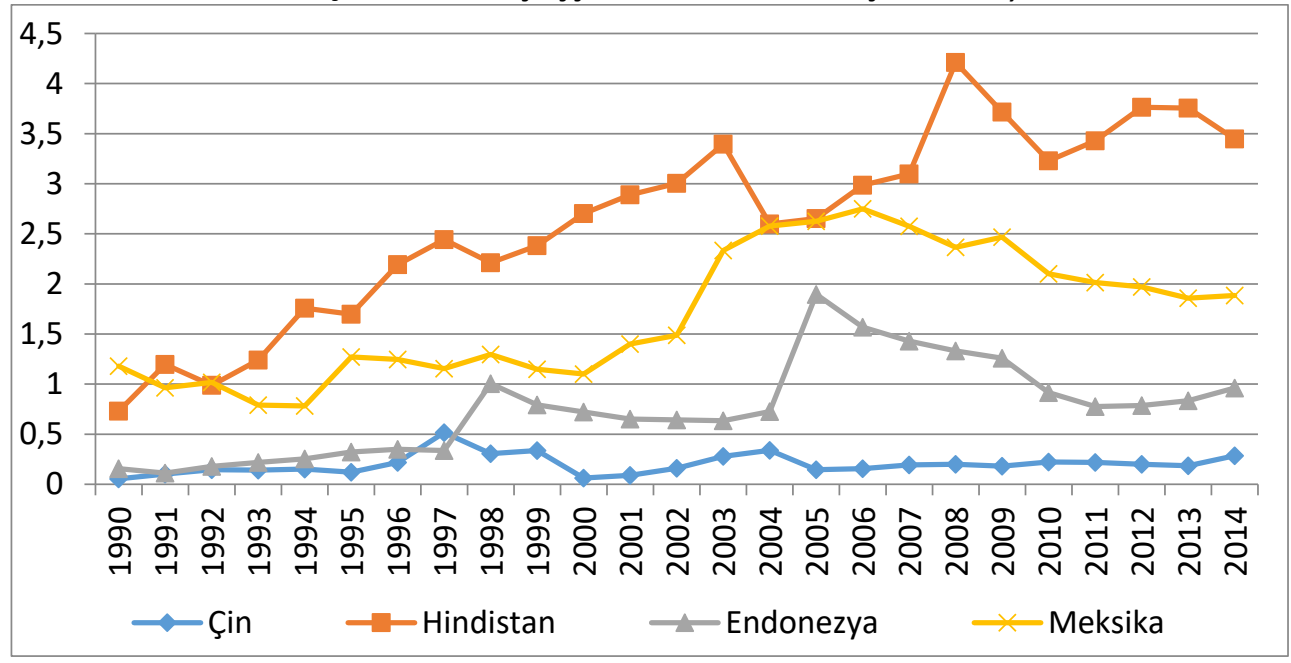

Kaynak: World Bank (2017), http://databank.worldbank.org/data/home.aspx 
Şekil 4: Yurtdışı Iş̧̧i Gelirlerinin GSYiH Iç̧indeki Payları

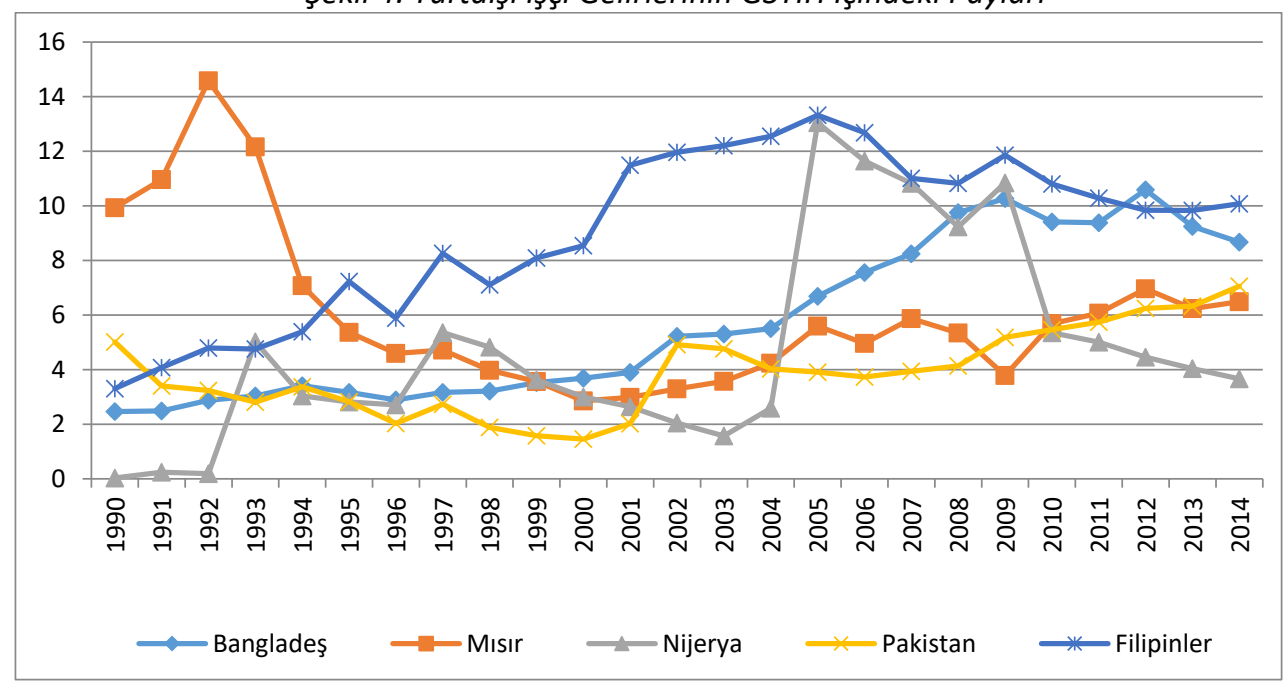

Kaynak: World Bank (2017), http://databank.worldbank.org/data/home.aspx

Çalışmada kullanılan veriler ile açıklamalarına ve veri kaynaklarına ilişkin bilgiler Tablo 1'de özetlenmiştir. Serileri olası değişen varyans ve kısmen de otokorelasyona karşı koruyabilmek için oransal değişkenler olmayan RDK, kişi başına milli gelir (KBMG) ve ticarete açıklık değişkenlerinin doğal logaritmik dönüşümü yapılmış ve o şekilde analize dâhil edilmiştir.

Tablo 1: Kullanılan Değişkenler, Açıklamaları ve Veri Kaynakları

\begin{tabular}{|c|c|c|c|}
\hline Değişkenler & Sembol & Açıklama & Kaynak \\
\hline Reel Döviz Kuru & $R D K$ & TUFE Bazlı, $2010=100$ & WB-WDI, 2017 \\
\hline Yurtdışı Iş̧̧i Gelirleri & YiG & Yurtdışı İşçi Gelirlerinin GSYH İçindeki Payı (\%) & WB-WDI, 2017 \\
\hline Kamu Harcamaları & KH & Kamu Harcamalarının GSYH İçindeki Payı (\%) & WB-WDI, 2017 \\
\hline Kişi Başına Milli Gelir & KBMG & Satın alma Gücü Paritesine Göre (Cari \$) & WB-WDI, 2017 \\
\hline Dış Ticaret Hadleri & DTH & İhracat Fiyat Endeksinin İthalat Fiyat Endeksine Oranı & WB-WDI, 2017 \\
\hline Ticarete Açıklık & $T A$ & $\begin{array}{l}\text { Mal ve Hizmet Ihracat ve İthalat Toplamının GSYH İçin- } \\
\text { deki Payı (\%) }\end{array}$ & WB-WDI, 2017 \\
\hline Net Yabancı Varlıklar & $N Y V$ & $\begin{array}{l}\text { Net Yabancı Varlıkların Toplam İhracat İçindeki Payı } \\
\text { (\%) }\end{array}$ & WB-WDI, 2017 \\
\hline Dış Yardım & $D Y$ & Net Resmi Dış Yardımların GSYH İçindeki Payı (\%) & WB-WDI, 2017 \\
\hline
\end{tabular}


Çalışmanın teorik modeli, ilgili literatürden (Bourdet ve Falck, 2003; Amuedu-Dorantes ve Pozo, 2004; Rabbi vd., 2013; Nikas ve Blouchoutzi, 2014; Chowdhury ve Rabbi, 2014; Roy ve Dixon, 2016) yola çıkarak şu şekilde oluşturulmuştur:

$$
R D K=f(Y i G, K H, K B M G, D T H, T A, N Y V, D Y)
$$

Çalışmada, bütüncül bir yaklaşımla, açıklayıcı (bağımsız) değişkenlerin RDK'nu (bağımlı değişken) hangi yönde ve ne derece etkilediklerinin incelenmesi amacıyla oluşturulan uzun dönem doğrusal panel regresyon modeli şu şekildedir:

$$
\begin{gathered}
R D K_{i t}=B_{0}+B_{1} Y i G_{i t}+B_{2} K H_{i t}+B_{3} K B M G_{i t}+B_{4} D T H_{i t}+B_{5} T A_{i t}+B_{6} N Y V_{i t}+B_{7} D Y_{i t}+u_{i t} \quad \text { (2) } \\
(i=1,2,3, \ldots . .9 ; \quad t=1990,1991, \ldots ., 2014) \\
(N=9) \quad(T=25)
\end{gathered}
$$

Denklem 2'de yer alan tüm değişkenler Tablo 1'de gösterildiği şekildeyken, $i$ ülkeyi, $t$ yılı, $b_{0}$ bir sabiti ve $u_{i t}$ hata terimini göstermektedir. KBMG değişkeni, Balassa-Samuelson etkisini (teknolojik gelişme düzeyindeki farklılıkları) görmek amacıyla modelde yer alırken, 1997 Asya krizini temsilen modele bir yapay değişken (dummy variable) eklenmiştir. Balassa-Samuelson etkisine göre, teknolojik gelişme düzeyindeki olumlu gelişmeler dolayısıyla verimlilikte yaşanan artışlar, ticarete konu olan malların üretim maliyetlerini düşürmekte ve bu sektörlerde reel ücret artışlarına yol açmaktadır. Ticarete konu olan sektörlerde fiyatlar uluslararası piyasalarda belirlendiği için bu malların fiyatı artmayacaktır. Ticarete konu sektörlerdeki ücret artışı aynı zamanda ticaret dışı sektörlere de yansıyacak, fakat bu sektörlerde verimlilik artışı meydana gelmediği için ticarete konu olmayan malların fiyatı artacaktır. Genel fiyat düzeyinde artışa yol açan bu durum, reel döviz kuru üzerinde değerlenme yönünde baskıya yol açmaktadır. Bu çalışmada RDK, ulusal para birimi cinsinden yurtdışı cari genel fiyat düzeyinin, ulusal para birimi cinsinden yurtiçi cari genel fiyat düzeyine oranı şeklinde tanımlanmıştır. Bu doğrultuda, nominal döviz kurundaki bir düşüş, ulusal para biriminin yabancı para birimi cinsinden değerindeki bir artışı ifade etmektedir. Diğer şeyler sabitken, cari reel döviz kurunda bir düşüşe yol açan bu duruma göre, Denklem 2'deki modelin tahmini sonucunda YíG'nin katsayısının negatif çıkması, bu gelir akımlarının ulusal para biriminde bir reel değerlenme etkisi yarattığı ve $\mathrm{HH}$ belirtilerinin olduğu şeklinde yorumlanmaktadır.

Denklem 2'de belirtilen regresyon modeli, serilerin özelliklerine uygun olarak dengeli panel veri analizi prosedürü takip edilerek tahmin edilmiştir. $N$ sayıda birimin ve her birime ait $T$ sayıda gözlemin olduğu panel veri setleri için genel olarak doğrusal panel veri modeli kısaca şu şekildedir:

$$
\begin{aligned}
& Y_{i t}=\beta_{0 i t}+\sum_{k=1}^{K}\left(\beta_{k i t} X_{k i t}+u_{i t}\right) \quad(i=1,2, \ldots ., N ; t=1,2, \ldots, T) \\
& Y_{\mathrm{t}}=\alpha+\mathrm{x}_{\mathrm{it}} \beta+\mathrm{u}_{\mathrm{it}} \\
& \mathrm{u}_{\mathrm{it}}=\mu_{\mathrm{i}}+\mathrm{v}_{\mathrm{it}}
\end{aligned}
$$

Panel veri analiz prosedüründe, her bir birimde gözlenemeyen bireysel etkiler ortaya çıkabilmektedir. Denklik 5 'teki $\mu_{\mathrm{i}}$ gözlenemeyen bireysel etkileri ifade ederken, $v_{\text {it }}$ geriye kalan hata terimini ifade etmektedir. Panel veri modelleri, parametrelerin birim ve/veya zaman göre değer almasına bağlı olarak farklı biçimlerde sınıflandırılmaktadır. Eğer panel verideki gözlenemeyen bireysel etkiler, hata terimi gibi, tesadüfi bir değişken olarak ele alınırsa rassal etkiler; her bir 
yatay kesit gözlem için tahmin edilen bir parametre olarak ele alınırsa sabit etkiler söz konusudur. Sabit etkiler modelinde birimlerin davranışlarındaki farklılıklar sabit terimdeki farklılıklarla temsil edilmektedir. Sabit etkiler ve rassal etkiler modellerinin yanı sıra, modeldeki bütün yataykesitler için ortak bir sabit terim tahmin eden havuzlanmış en küçük kareler modeli bulunmaktadır. Bu modelde her bir yatay kesite ait belirli etkileri yansıtan kukla değişkenler olmadan bütün ülkelerin verileri bir havuzda toplanmakta ve bağımsız değişkenlerin bağımlı değişken üzerindeki etkileri incelenmektedir (Sayılgan ve Süslü, 2011: 84). Sabit etkiler ve rassal etkiler modellerinin her ikisinde de grup etkisi ve/veya zaman etkisinin varlığına bağlı olarak tek-yönlü ya da çift-yönlü modeller ortaya çıkabilmektedir. Bu nedenle sayılan durumları dikkate alan $F, L M$ ve Honda testlerinin sonuçlarına göre zaman ve grup etkilerinin modele dâhil edilip edilmeyeceğine karar verilmektedir (Baltagi, 2005). Denklem 2'nin tahmin edilmesinde kullanılacak en uygun tahmincinin zaman ve grup etkilerini içerip içermeyeceğini belirlemek amacıyla yapılan testlerin sonuçları Tablo 2'de sunulmuştur. Tablo 2'de ayrıca içsellik problemin test edilmesi amacıyla Hausman testi sonuçlarına da yer verilmiştir.

Tablo 2: Zaman ve Grup Etkileri Belirleme Testleri

\begin{tabular}{ccc}
\hline & $\boldsymbol{t}$ istatistikleri & $\boldsymbol{P}^{* *}$ \\
\hline F grup sabit etkiler modeli & $3288,92^{* *}$ & 0,000 \\
\hline$F$ zaman sabit etkiler modeli & $3,3321^{* *}$ & 0,000 \\
\hline$F$ çift yönlü sabit etkiler modeli & $880,34^{* *}$ & 0,000 \\
\hline$L M$ grup rassal etkiler modeli & $1800,17^{* *}$ & 0,000 \\
\hline$L M$ zaman rassal etkiler modeli & $7,9469^{* *}$ & 0,004 \\
\hline$L M$ çift yönlü rassal etkiler modeli & $1808,12^{* *}$ & 0,000 \\
\hline Honda grup rassal etkiler modeli & $42,428^{* *}$ & 0,003 \\
\hline Honda zaman rassal etkiler modeli & $-1,819$ & 0,997 \\
\hline Honda çift yönlü rassal etkiler modeli & $28,008^{* *}$ & 0,000 \\
\hline Hausman Testi & 4,630 & 0,705 \\
\hline
\end{tabular}

Not: ** istatistiklerin \%5 düzeyinde anlamlı olduğunu göstermektedir.

Hausman testi sonuçları gözlenemeyen bireysel etkilerle açıklayıcı değişkenler arasında ilişki olmadığını (içsellik probleminin olmadığını) göstermektedir. F, LM ve Honda testi sonuçları ise zaman ve grup etkilerinin her ikisinin de modele dâhil edilmesi gerektiğine işaret etmektedir. Buradan yola çıkarak model tahmininde çift yönlü rassal etkiler (two-way random effect) tahmincisi kullanılmıştır. Uygun tahminci belirlendikten sonra model tahminine geçmeden önce model istikrar testleri bağlamında değişen varyans ve otokorelasyon problemlerini sorgulamaya yönelik bazı testler yapılmış ve sonuçlar Tablo 3'te sunulmuştur. 
Eskişehir Osmangazi Üniversitesi iiBF Dergisi

Tablo 3: Değişen Varyans ve Otokorelasyon Testi Sonuçları

\begin{tabular}{ccc}
\hline Değişen Varyans & $\boldsymbol{t}$ istatistikleri & $\boldsymbol{P}^{* *}$ \\
\hline$L M h$ rassal etkiler modeli & $198,84^{* *}$ & 0,000 \\
\hline Otokorelasyon & $\boldsymbol{t}$ istatistikleri & $\boldsymbol{P}^{* *}$ \\
\hline$L M_{\mu \rho}$ rassal etkiler modeli & $1811,54^{* *}$ & 0,000 \\
\hline$L M_{\mu / \rho}$ rassal etkiler modeli & $1734,69^{* *}$ & 0,000 \\
\hline$L M_{\rho / \mu}$ rassal etkiler modeli & $11,368^{* *}$ & 0,000 \\
\hline
\end{tabular}

Not: ${ }^{* *}$, istatistiklerin $\% 5$ düzeyinde anlamlı olduğunu göstermektedir.

Tablo 3'te gösterilen $L M$ test sonuçlarına göre, çift yönlü rassal etkiler modeline göre değişen varyans ve otokorelasyon sorununun olduğu anlaşılmaktadır. Bu nedenle regresyon modelimiz, çift yönlü rassal etkiler tahmincisi eşliğinde değişen varyans ve otokorelasyon sorunlarını da dikkate alan dönem ağırlıklarına (period weights) göre panel düzeltilmiş standart hata ( $p a-$ nel-corrected standard error-PCSE) yöntemiyle tahmin edilmiştir. Standart hataların sağlamlığını ve direncini de artıran bu yaklaşım yoluyla yapılan tahmin sonuçları Tablo 4'te sunulmuştur.

Tablo 4: Regresyon Modeli Tahmin Sonuçları

\begin{tabular}{|c|c|c|c|c|}
\hline Değişkenler & Katsayı & Standart Hata & $t$ istatistikleri (PCSE) & $P^{* *}$ \\
\hline Yig & $-0,082$ & 0,017 & $-4,859 * *$ & 0,000 \\
\hline$\kappa H$ & $-2,695$ & 0,381 & $-7,065 * *$ & 0,000 \\
\hline KBMG & $-0,059$ & 0,196 & $-0,304$ & 0,761 \\
\hline DTH & 0,711 & 0,183 & 3,879 & 0,000 \\
\hline$T A$ & 1,352 & 0,367 & $3,675^{* *}$ & 0,000 \\
\hline$N Y V$ & $-0,636$ & 0,116 & $-5,489 * *$ & 0,000 \\
\hline$D Y$ & 0,027 & 0,035 & 0,777 & 0,438 \\
\hline DUM & 0,671 & 0,105 & $6,368^{* *}$ & 0,000 \\
\hline C & 2,017 & 0,731 & $2,758 * *$ & 0,006 \\
\hline Düz. $R^{2}=0,453$ & & istiğ $\mathrm{i}=24,241 * *$ & $p=0,000$ & \\
\hline
\end{tabular}

Not: ${ }^{* *}$ istatistiklerin \%5 düzeyinde anlamlı olduğunu göstermektedir. Rassal etki modelinin tahmininde Swamy-Arora yöntemi kullanılmıştır. 
Ekonometrik model tahmini sonuçlarına göre, istatistiki olarak anlamlı olduğu görülen YiG'ndeki artışın RDK'nda düşüşe yol açtığı görülmektedir. Bu bulgu, bir HH belirtisi olarak, YiG'ndeki artışın ulusal para birimlerinde reel değerlenme etkisi yarattığına işaret etmektedir. Yí'ndeki \%1'lik artış ev sahibi ülkelerin yerel para birimlerinde \% 0,082 oranında reel değerlenme etkisi yaratmaktadır. Yine istatistiki olarak anlamlı olduğu görülen kamu harcamalarındaki ve net yabancı varlıklardaki artışın da reel değerlenme yönünde işlev gördüğü anlaşılmaktadır. Kamu harcamalarının RDK üzerinde ne yönde etkide bulunacağı net olmamakla birlikte, elde edilen sonuçlar kamu harcamalarının daha çok ticarete konu olmayan mal ve hizmetlere yönelik olması nedeniyle bu malların fiyatlarını yükselttiğine ve bu nedenle de bir reel değerlenme etkisi yarattığına işaret etmektedir. Ayrıca kamu harcamalarının reel değerlenme yönünde etkide bulunması, bu harcamaların bir kısmının dış borçla finanse edildiği şeklinde çıkarımlarda bulunmaya da yol açabilir. Teorik beklentilerle uyumlu olan net yabancı varlıkların RDK üzerindeki negatif etkisine göre, net yabancı varlıklardaki artışın tıpkı diğer sermaye akımlarında olduğu gibi ihracatta rekabet edebilirlik gücünü sınırlandırdığı anlaşılmaktadır. Dış ticaret hadleri ve ticarete açıklık düzeyindeki olumlu gelişmelerin reel değerlenmeye karşıt yönde etkide bulunduğu görülürken, KBMG ve dış yardım büyüklüklerinin istatistiki olarak anlamlı olmadığı görülmektedir. Dış ticaret hadlerinin RDK üzerindeki etkisi gelir ve ikame etkilerinin büyüklüklerine bağlıdır. Gelir etkisi, ihracat fiyatlarındaki bir artışın toplam geliri artırarak ticarete konu olmayan mal ve hizmetlere yönelik talep ve fiyat artışına yol açtı̆̆ını ifade ederken, ikame etkisi ticarete konu olmayan mal ve hizmetlerin fiyatlarındaki nispi azalışa göndermede bulunmaktadır. Buna göre, elde edilen sonuçlar ikame etkisinin gelir etkisinden daha ağır bastığını göstermektedir. Teorik beklentilerle uyumlu olduğu gözüken ticarete açıklık tahmin sonucuna göre, tarife ve kotalar gibi ticaret engellerinin azaltılması dolayısıla ticarete açıkıı düzeyinde yaşanan olumlu gelişmelerin, ticarete konu olan malların ticarete konu olmayan mallara göre nispi fiyatını düşürdüğü ve bu sayede ihracatta rekabet edebilirlik gücünü artırdığı söylenebilir. Teknolojik gelişme düzeyindeki farklılıkları temsilen modele dâhil edilen KBMG değişkeni katsayısının işareti teorik beklentilerle uyumlu olmasına rağmen istatistiki olarak anlamsız olması, Balassa-Samuelson etkisinin geçerli olmadığını göstermektedir. Yine çalışmada yer alan ülkelere yapılan resmi dış yardımların da ulusal para birimleri üzerinde bir reel değerlenme etkisi yaratmadığı sonucuna varılmıştır.

\section{Sonuç}

YíG'nin uluslararası sermaye akımları içerisinde artan önemi, bu akımların ev sahibi ülke ekonomilerine ne yönde ve nasıl katkı sundukları üzerine yoğun araştırmaları da beraberinde getirmiştir. YiG'nin ev sahibi ülkede yoksulluk düzeyini azaltması ve refah düzeyini yükseltmesi gibi pozitif makroekonomik sonuçlar yarattığı bulgularına ulaşan çalışmaların yanı sıra, yakın dönem literatüründe YiG'nin dolaylı yollarla olumsuz makroekonomik sonuçlar doğurabileceği üzerinde de durulmaktadır. Bu olumsuz makroekonomik sonuçların temel olarak reel kur aracıIığıyla gerçekleşeceği vurgulanmaktadır. Buna göre, YiG'ndeki artışın ev sahibi ülkenin yerel para biriminde bir reel değerlenmeye yol açması ve bu yolla da ticarete konu olan mallarda rekabet gücünü zayıflatması dolayısıyla ekonomik büyümeyi negatif yönde etkilemesi (Hollanda Hastalığı-HH) söz konusudur.

Bu çalışmada, en fazla YíG elde eden ülkeler arasından seçilen 9 ülkeye ait 1990-2014 dönemi yıllık panel verileri kullanılarak YiG'nin ev sahibi ülkelerde bir HH etkisi yaratıp yaratmadığının test edilmesi amaçlanmıştır. Çift yönlü rassal etkiler tahmincisinin kullanıldığı analizden elde edilen bulgular, bir HH belirtisi olarak, YiG'nin ev sahibi ülkelerin yerel para birimlerinde 
bir reel değerlenme etkisi yarattığına işaret etmektedir. Genellikle doğal kaynak gelirlerindeki ani artışlara bağıı olarak ortaya çıkan HH etkilerini bertaraf etmeye yönelik getirilen çözüm önerileri, bu gelirlerin ticarete konu olan sektörlere kanalize edilmesi, araştırma geliştirme faaliyetlerinin ve beşeri sermayenin gelişimi amacıyla kullanılması odağında birleşmektedir. Bununla birlikte YiG genellikle doğrudan hane halkının eline geçtiği için, devlet eliyle böyle bir çözüm yolu pek mümkün gözükmemektedir. Dolayısıyla Yíg'nin sebep olacağı olası bir reel değerlenmeye karşılık, YiG'nin gelişim trendi takip edilerek bu gelir akımlarının ciddi boyutlara ulaştığı dönemlerde Merkez Bankaları'nın reel değerlenmeye karşıt yönde aktif piyasa işlemleri gerçekleştirmelerinin etkin bir uygulama olabileceği düşünülmektedir. Ayrıca hane halkını, YíG'ni ticarete konu olmayan sektörlerden ziyade ticarete konu olan sektörlerde harcamaya (ya da değerlendirmeye) yöneltecek teşvik ve uygulamaların da faydalı olabileceği düşünülmektedir.

YíG'nin makroekonomik etkileri sorgulanırken reel döviz kuru dinamiklerinin daha net görülebilmesi için incelenen değişkenlerin daha düşük frekansta ele alınması önemlidir. Bunun için çeyrek yıllık verilerle çalışılmak istense de, çalışmamızın temel kısıtı olarak, modelde yer alan tüm değişkenlere ilişkin çeyrek yıllık verilere ulaşılamadığı için yıllık frekansta çalışılmıştır. Dolayısıyla gelecekteki çalışmalarda daha düşük frekansta verilerin kullanılmasının reel döviz kuru dinamiklerinin daha net görülebilmesi bakımından faydalı olacağı düşünülmektedir. 


\section{Kaynaklar}

Acosta, Pablo; Calderon, Cesar; Fajnzylber, Pablo; Lopez, Humberto (2008), "What is the Impact of International Remittances on Poverty and Inequality in Latin America?", World Development, Vol. 36, No. 1: 89-114.

Adams, Richard H.; Page, John (2005), "Do International Migration and Remittances Reduce Poverty in Developing Countries?”, World Development, Vol. 33, No. 10: 1645-1669.

Amuedo-Dorantes, Catalina; Pozo, Susan (2004), “Workers' Remittances and the Real Exchange Rate: A Paradox of Gifts", World Development, Vol. 32, No. 8: 1407-1417.

Arı, Ayse; Özcan, Burcu (2012), “Hollanda Hastalığı: Gelişmekte Olan Ülkeler Üzerine Bir Uygulama”, Sosyo Ekonomi, 2: 155-171.

Bal, Harun (2011) "iktisadi Gelişme ve Doğal Kaynaklar: Geçiş Ekonomileri Çerçevesinde Bir İnceleme”, Ç.Ü. Sosyal Bilimler Enstitüsü Dergisi, Cilt 20, Sayı 1: 87-104.

Baltagi, Badi (2005), “Econometrics Analysis of Panel Data”, 3rd Edition, London: John Wiley \& Sons.

Bourdet, Yves; Falck, Hans (2003), “Emigrants' Remittances and Dutch Disease in Cape Verde”, Kristianstad University College Department of Business Studies Working Paper Series, No. 11: 1-21.

Chowdhury, Mamta B.; Rabbi, Fazle (2014), "Workers' Remittances and Dutch Disease in Bangladesh", The Journal of International Trade \& Economic Development, Vol. 23, No. 4: 455-475.

Corden, Warner Max (1984), "Booming sector and Dutch Disease Economics: Survey and Consolidation”, Oxford Economic Papers New Series, Vol. 36, No. 3: 359-380.

Corden, W. Max; Neary, J. Peter (1982), "Booming sector and De-industrialisation in a Small Open Economy". The Economic Journal, Vol. 92, No. 368: 825-848.

Gylfason, Thorvaldur. (2001), “Natural resources and economic growth: What is the connection?" CESifo Working Paper Series, No. 530: 1-20.

John Jonathan Di (2011), "Is There Really a Resource Curse? A Critical Survey of Theory and Evidence", Global Governance, Vol. 17, No. 2: 167-184.

Jongwanich, Juthathip (2007), “Worker's Remittances, Economic Growth and Poverty in Developing Asia and the Pacific Countries", UNESCAP Working Paper, WP/07/01, 1-27.

Lartey, Emmanuel K. K.; Mandelman, Federico S.; Acosta, Pablo A. (2012), “Remittances, Exchange Rate Regimes and the Dutch Disease: A Panel Data Analysis", Review of International Economics, Vol 20, No. 2: 377-395.

Martins, Pedro MG (2013), "Do Large Capital Inflows Hinder Competitiveness? The Dutch Disease in Ethiopia", Applied Economics Letters, Vol. 45, No. 8: 1075-1088.

Nikas, Christos; Blouchoutzi, Anastasia (2014), “Emigrants'Remittances and the "Dutch Disease” in Small Transition Economies: the Case of Albania and Moldova", Revista Romana de Statistica, No 1: 45-65.

Oomes Nienke; Kalcheva, Katerina (2007), “Diagnosing Dutch disease: Does Russia Have the Symptoms?”, BOFIT Discussion Papers, No. 102: 1-41.

Ratha, Dilip (2013), "The Impact of Remittances on Economic Growth and Poverty Reduction". Policy Brief 8: 1-13.

Roy, Ripon; Dixon, Robert (2016), “Workers remittances and Duch Disease in South Asian Countries", Applied Economic Letters, Vol. 23, No. 6: 407-410.

Sayılgan, Güven; Süslü, Cemil (2011), “Makroekonomik Faktörlerin Hisse Senedi Getirilerine Etkisi: Türkiye ve Gelişmekte Olan Piyasalar Üzerine Bir İnceleme”, BDDK Bankacılık ve Finansal Piyasalar Dergisi, Vol. 5, No. 1: 73-96.

Sy, Mouhamadou; Tabarraei, Hamidreza (2010), "Capital Inflows and Exchange Rate in LLCs: The Dutch Disease Problem Reviseted", PSE Working Paper, No 26. 1-31.

World Bank Group (2016), “Migration and Remittances_Recent Developments and Outlook”, Migration and Development Brief 26: 1-48.

World Bank (2017). http://databank.worldbank.org/data/home.aspx, (Erişim: 04.03.2017). 
Eskişehir Osmangazi Üniversitesi iiBF Dergisi 